\title{
ANALISIS FAKTOR PENYEBAB KESULITAN BELAJAR IPA SISWA SMP KOTA SEMARANG
}

\author{
Arghob Khofya Haqiqi \\ Sekolah Tinggi Agama Islam Kudus \\ e-mail: arghobhaqiai@stainkudus.ac.id
}

\begin{abstract}
Abstrak
Penelitian ini bertujuan untuk mengetahui (1) faktor faktor yang mempengaruhi kesulitan belajar pada siswa SMP; (2) menganalisis kaitan kesulitan belajar terhadap nilai ujian nasional. Analisis data dilakukan secara deskriptif, data yang diperoleh dalam penelitian ini berupa data hasil belajar siswa dan hasil pengisian angket. Hasil dari analisis tersebut didapatkan faktor faktor penyebab kesulitan belajar IPA siswa SMP di Kota Semarang meliputi faktor internal dan faktor eksternal. Faktor kesulitan belajar dari faktor internal siswa berupa aspek bakat, minat, motivasi dan intelegensi. Sedangkan faktor eksternal siswa berupa fasilitas sekolah, guru, sarana prasarana dan aktivitas siswa. Hasil analisis juga menunjukkan bahwa adanya faktor kesulitan belajar IPA di sekolah berkaitan terhadap hasil nilai ujian nasional. Besarnya presentase serapan materi IPA pada ujian nasional juga sebanding dengan besarnya angka presentase kesulitan belajar yang dialami oleh sekolah tersebut.
\end{abstract}

Kata Kunci: Analisis, Faktor Kesulitan Belajar, IPA

\begin{abstract}
This study aimed at determining (1) the factors that influence the students learning difficulties in junior high school; (2) analyzed the relationship between learning difficulties and national exam scores. Data analysis is carried out descriptively. The data obtained in this study are the data of student learning outcomes and the results of questionnaires. The results of the analysis found that the factors influencing the learning difficulties of junior high school students in Semarang City included into internal and external factors. The internal factors of students driven from the aspects of talent, interest, motivation and intelligence. While the external factors came from the aspects of school facilities, teachers and student activities. The results of the analysis also proved the correlation between science learning difficulties and the results of national examination scores. The magnitude of the absorption percentage of science material on national exams is also comparable to the magnitude of the percentage of learning difficulties experienced by the school.
\end{abstract}

Keywords: Analyze, Difficulty learning factors, Science

\section{PENDAHULUAN}

Kesulitan belajar merupakan suatu keadaan dimana peserta didik tidak dapat belajar secara baik, disebabkan adanya ancaman, hambatan maupun gangguan dalam belajar (Djamarah, 2011). Hamalik (2006) menyatakan bahwa jika siswa mengalami kegagalan atau 
kemunduran dalam hasil belajar, hal itu berarti ada kesulitan yang dihadapi selama pembelajaran. Kesulitan belajar pada sekolah menengah pertama salah satunya terjadi pada mata pelajaran IPA. Mata pelajaran IPA atau sains menuntut intelektualitas yang relatif tinggi. Checkley (2010) mengemukakan bahwa IPA merupakan mata pelajaran yang penting dan patut dikuasai oleh siswa pada era kemajuan teknologi dan informasi saat ini. Dengan demikian penguasaan terhadap mata pelajaran IPA merupakan sesuatu yang tidak dapat dihindari oleh siswa dalam proses pendididikan dan pembelajaran (Ukoh, 2012).

Hasil observasi yang dilakukan terhadap beberapa sekolah di Kota Semarang menunjukkan hasil prestasi belajar masih kurang maksimal. Guru dihadapkan dengan sejumlah karakterisktik siswa yang beraneka ragam dalam kegiatan pembelajaran di sekolah. Ada siswa yang dapat menempuh kegiatan belajarnya secara lancar dan berhasil tanpa mengalami kesulitan, namun di sisi lain tidak sedikit pula siswa yang justru dalam belajarnya mengalami berbagai kesulitan. Kesulitan belajar siswa ditunjukkan oleh adanya hambatan-hambatan tertentu untuk mencapai hasil belajar. Dalam penelitiannya Wahyudi (2006), ciri-ciri anak yang mengalami berkesulitan belajar antara lain anak yang mengalami kesulitan dalam mengerjakan tugas-tugas akademik sekolah, sehingga prestasi belajar yang dicapai jauh dari potensi yang sebenarnya

Elwan (2013) menjelaskan faktor-faktor yang menyebabkan kesulitan belajar siswa dapat berupa faktor internal yang berasal dari dalam diri yang bersangkutan dan faktor eksternal yang berasal dari luar diri yang bersangkutan. Rusilowati (2006) menjelaskan penyelidikan-penyelidikan yang dapat dilakukan untuk mengetahui kesulitan belajar siswa adalah dengan mengadakan observasi, analisis, interview, tes diagnostik, dan memanfaatkan dokumentasi . Dari kenyataan ini menunjukkan bahwa penguasaan siswa terhadap mata pelajaran IPA pada sekolah menengah pertama (SMP) masih bermasalah dan permasalahan yang dihadapi berbeda. Untuk itulah peneliti disini merasa penting untuk melalukan penelitian mengenai adanya faktor faktor kesulitan belajar IPA pada siswa Sekolah Menengah Pertama (SMP) di Kota Semarang.

\section{METODE}

Metode penelitian ini adalah metode kualitatif deskriptif. Sampel penelitian adalah siswa SMP kelas VIII di Kota Semarang. Sampel ditentukan secara cluster sampling menurut peringkat sekolah dilihat dari hasil nilai ujian nasional. SMP dan jumlah sampel yang terpilih sebagai sampel dapat dilihat pada Tabel 1.

\section{Tabel 1. Sampel Penelitian berdasarkan Peringkat Sekolah}




\begin{tabular}{lll}
\hline & Sekolah & Jumlah Sampel \\
\hline \multirow{2}{*}{ Kategori I } & SMP N 2 Semarang & 29 \\
\multirow{2}{*}{ Kategori II } & SMP I Al Azhar 14 & 22 \\
& SMP N 27 Semarang & 32 \\
\multirow{2}{*}{ Kategori III } & SMP Nurul Islam & 25 \\
& SMP N 35 Semarang & 24 \\
\hline
\end{tabular}

Data yang diperoleh dalam penelitian ini berupa data hasil belajar siswa, dan hasil pengisian angket. Setelah data terkumpul dilakukan reduksi data yang bertujuan untuk memfokuskan pada hal-hal yang akan diteliti yaitu menganalisis jawaban siswa yang telah dipilih dalam penelitian (Sugiyono. 2005). Analisis data dilakukan secara deskriptif. Apabila siswa membuat kesalahan dari setiap langkah dalam menyelesaikan soal tes uraian, maka siswa tersebut dinyatakan mengalami kesulitan mempelajari IPA.

\section{HASIL DAN PEMBAHASAN}

Faktor kesulitan belajar terbagi menjadi faktor internal dan faktor eksternal. Hasil analisis data menunjukkan presentase faktor kesulitan belajar pada siswa sekolah menegah pertama di Kota Semarang untuk faktor internal dapat dilihat pada Grafik 1.

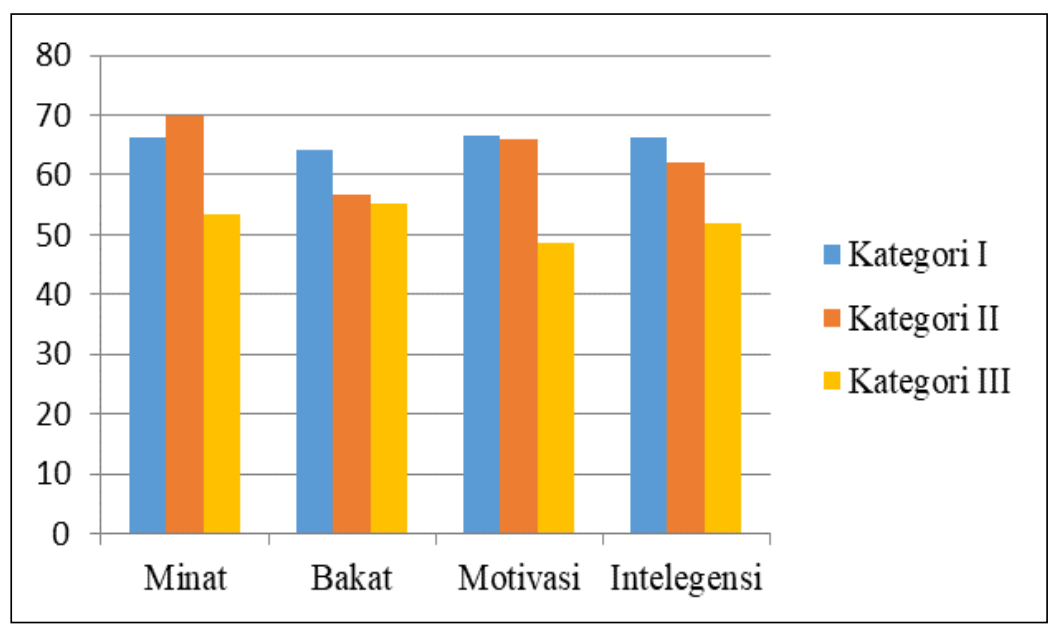

Grafik 1. Presentase Faktor Internal Kesulitan Belajar

Penjelasan untuk masing-masing faktor penyebab kesulitan belajar dapat dijelaskan sebagai berikut: Pertama, pada aspek minat belajar sekolah kategori I 66,33\% (cukup menyebabkan kesulitan belajar), sekolah kategori II 69,8 \% (cukup menyebabkan kesulitan belajar) sedangkan sekolah kategori III 53,33 \% (kuat menyebabkan kesulitan belajar

Kedua, Pada aspek bakat diperoleh persentase sekolah kategori I menunjukkan bahwa perolehan persentase untuk aspek bakat belajar IPA sebesar 64,12 \% (cukup menyebabkan kesulitan belajar), sekolah kategori II 56,58 \% (cukup menyebabkan kesulitan belajar) sedangkan sekolah kategori III 55,36 \% (kuat menyebabkan kesulitan belajar). 
Menurut Suyanto (2017) bakat mempunyai peran penting pada diri pembelajar dalam proses pembelajaran, yaitu memberikan dampak terhadap hasil belajar sebagai hasil akhir dari proses pembelajaran

Ketiga, pada aspek motivasi sekolah kategori I menunjukkan bahwa perolehan persentase untuk motivasi belajar IPA sebesar 66,63 \% (cukup menyebabkan kesulitan belajar), sekolah kategori II 65,86 \% (cukup menyebabkan kesulitan belajar) sedangkan sekolah kategori III 48,52\% (kuat menyebabkan kesulitan belajar). Anni (2006) menyatakan motivasi bukan saja penting karena menjadi faktor penyebab belajar, namun juga memperlancar belajar dan hasil belajar

Keempat, pada aspek intelegensi diperoleh persentase sekolah kategori I sebesar 66,33 \% (cukup menyebabkan kesulitan belajar), sekolah kategori II 62,18 \% (cukup menyebabkan kesulitan belajar) sedangkan sekolah kategori III 51,95 \% (kuat menyebabkan kesulitan belajar).

Hasil analisis angket faktor faktor kesulitan belajar IPA untuk faktor eksternal dapat dilihat pada Grafik 2.

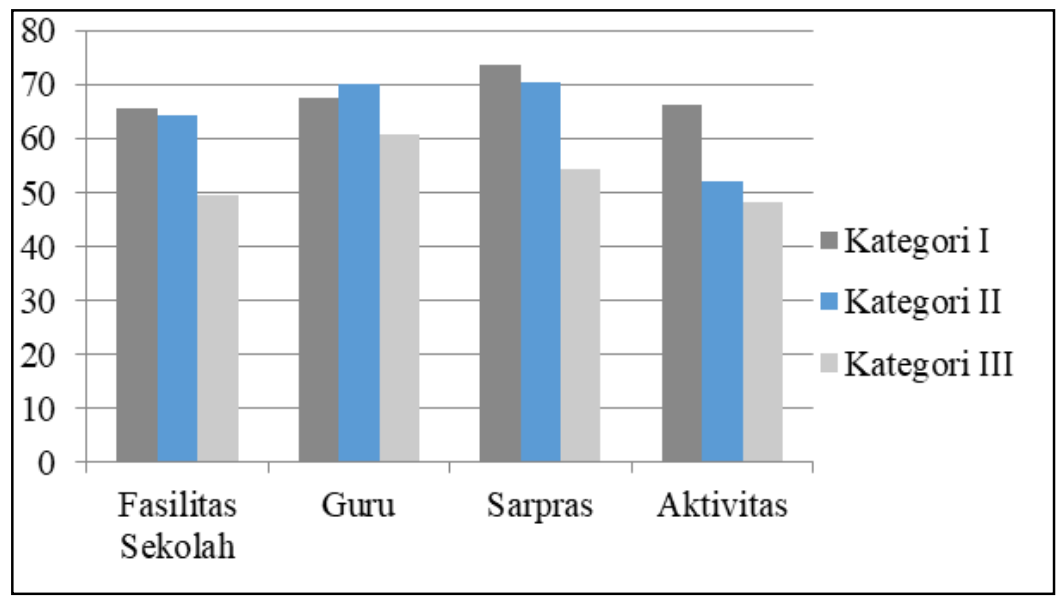

Grafik 2. Presentase Faktor Eksternal Kesulitan Belajar

Dari grafik faktor kesulitan belajar tersebut dapat dijelaskan yang pertama untuk aspek fasilitas sekolah dalam penelitian ini sekolah kategori I sebesar 66,33 \% (cukup menyebabkan kesulitan belajar), sekolah kategori II 62,18\% (cukup menyebabkan kesulitan belajar) sedangkan sekolah kategori III 49,95 \% (kuat menyebabkan kesulitan belajar). Menurut Misbach (2003) fasilitas belajar di sekolah sangat mempengaruhi prestasi belajar siswa. Apabila fasilitas belajar di sekolah tidak memadai dan kuantitas pemanfaatan fasilitas minim, maka tidak mungkin akan dicapai prestasi belajar siswa yang diharapkan.

Kedua, pada aspek guru diperoleh persentase sekolah kategori I 67,53 \% (cukup menyebabkan kesulitan belajar), sekolah kategori II 70,08 \% (cukup menyebabkan kesulitan belajar) sedangkan sekolah kategori III 60,98 \% (cukup menyebabkan kesulitan belajar) 
Ketiga, pada aspek sarana prasarana menunjukkan bahwa persentase sekolah kategori I 73,48\% (cukup menyebabkan kesulitan belajar), sekolah kategori II 70,08\% (cukup menyebabkan kesulitan belajar) sedangkan sekolah kategori III 53,12\% (kuat menyebabkan kesulitan belajar). Keempat, pada aspek aktivitas diperoleh persentase sekolah kategori I $65,33 \%$ (cukup menyebabkan kesulitan belajar), sekolah kategori II 71,18\% (cukup menyebabkan kesulitan belajar) sedangkan sekolah kategori III 58,91\% (kuat menyebabkan kesulitan belajar). Berdasarkan pertanyaan yang digunakan pada angket dapat diketahui bahwa siswa aktif mengikuti kegiatan keorganisasian dan hal ini berimbas pada tidak teraturnya jadwal dalam belajar IPA. Menurut Marantika (2007), keaktifan organisasi mempunyai pengaruh yang negatif terhadap prestasi belajar. Siswa cenderung terbagi waktu, tenaga serta pikirannya sehingga siswa mengalami kesulitan dalam membagi waktu belajar.

Hasil nilai UN mata pelajaran IPA dari data puspendik dapat dilihat pada Tabel 2 dan Tabel 3.

Tabel 2. Nilai UN IPA Siswa SMP Negeri di Kota Semarang

\begin{tabular}{lllll}
\hline \multirow{2}{*}{ No } & Nama Sekolah & \multicolumn{3}{c}{ Nilai UN IPA } \\
\cline { 3 - 5 } & & 2014 & 2015 & 2016 \\
\hline 1 & SMP N 2 Semarang & 9,04 & 8,64 & 8,63 \\
2 & SMP N 27 Semarang & 7,41 & 6,98 & 6,46 \\
3 & SMP N 35 Semarang & 5,56 & 4,71 & 5,58 \\
\hline
\end{tabular}

Tabel 3. Nilai UN IPA Siswa SMP Swasta di Kota Semarang

\begin{tabular}{llccc}
\hline \multirow{2}{*}{ No } & Nama Sekolah & \multicolumn{3}{c}{ Nilai UN IPA } \\
\cline { 3 - 5 } & & 2014 & 2015 & 2016 \\
\hline 1 & SMPI Al Azhar 14 & 8,58 & 8,05 & 8,32 \\
2 & SMP Nurul Islam & 6,89 & 4,86 & 6,21 \\
3 & SMP Kartika III-2 & 4,68 & 4,43 & 4,67 \\
\hline
\end{tabular}

Sedangkan untuk presentase serapan pembelajaran IPA pada materi cahaya pada hasil Ujian Nasional (UN) dari data puspendik dapat dilihat pada Tabel 4 dan Tabel 5. 
Tabel 4. Presentase Serapan Materi Cahaya pada UN Siswa SMP Negeri di Kota Semarang

\begin{tabular}{llccc}
\hline \multirow{2}{*}{ No } & Nama Sekolah & \multicolumn{3}{c}{ Serapan Materi Cahaya } \\
\cline { 3 - 5 } & & 2014 & 2015 & 2016 \\
\hline 1 & SMP N 2 Semarang & 86,8 & 88,53 & 88,41 \\
2 & SMP N 27 Semarang & 67,8 & 73,73 & 70,11 \\
3 & SMP N 35 Semarang & 49,16 & 46,01 & 47,83 \\
\hline
\end{tabular}

Tabel 5. Presentase serapan materi cahaya pada UN Siswa SMP Swasta di Kota Semarang

\begin{tabular}{lllll}
\hline & No & Nama Sekolah & \multicolumn{3}{c}{ Serapan Materi Cahaya } \\
\cline { 3 - 5 } & & 2014 & 2015 & 2016 \\
\hline 1 & SMPI Al Azhar 14 & 86,44 & 82,91 & 83,42 \\
2 & SMP Nurul Islam & 74,92 & 52,28 & 65,35 \\
3 & SMP Kartika III-2 & 45,62 & 50,32 & 46,33 \\
\hline
\end{tabular}

Hasil analisis menunjukkan bahwa adanya kesulitan belajar IPA di sekolah berkaitan juga terhadap hasil nilai ujian nasional (IPA). Besarnya presentase serapan materi cahaya pada ujian nasional juga sebanding dengan besarnya angka presentase kesulitan belajar yang dialami oleh sekolah tersebut. Dengan nilai UN yang diperoleh oleh sekolah kategori 1 lebih tinggi dibandingkan sekolah kategori II dan III, maka dapat terlihat terdapat kaitan yang relevan antara nilai UN dan besarnya tingkat kesulitan belajar yang dimiliki.

Kesulitan belajar mata pelajaran IPA pada siswa harus segera diatasi. Kesulitan belajar IPA yang berkelanjutan menyebabkan siswa kesulitan dalam memahami konsepkonsep IPA selanjutnya. Salah satu cara yang dapat dilakukan guru adalah melakukan diagnosis yang bertujuan untuk mengidentifikasi jenis dan penyebab kesulitan belajar. Hal ini didukung oleh penelitian yang dilakukan Ornek (2008) yang menyatakan bahwa dalam mengatasi masalah kesulitan belajar ini harus didiagnosa terlebih dahulu dan untuk selanjutnya diambil tindakan untuk mengatasi masalah tersebut.

\section{SIMPULAN}

Kesulitan belajar IPA pada siswa SMP di Kota Semarang memiliki perbedaan presentase yang dilihat dari ketiga kategori sekolah dikarenakan adanya faktor - faktor kesulitan yang berbeda-beda. Faktor kesulitan belajar dari faktor internal siswa berupa aspek bakat, minat, motivasi dan intelegensi. Sedangkan faktor eksternal siswa berupa fasilitas sekolah, guru, sarana prasarana dan aktivitas siswa. Kesulitan belajar IPA di sekolah juga berkaitan terhadap hasil nilai ujian nasional. Besarnya presentase serapan 
materi cahaya pada ujian nasional juga sebanding dengan besarnya angka presentase kesulitan belajar yang dialami oleh sekolah tersebut. Hasil penelitian ini dapat digunakan sebagai landasan awal untuk menentukan model ataupun pembelajaran yang bervariasi pada tiap sekolah. Hal ini disebabkan karena masing masing sekolah yang memiliki jenis dan tingkat kesulitan belajar yang berbeda-beda.

\section{DAFTAR PUSTAKA}

Anni, C.T. 2006. Psikologi Belajar. Semarang: UPT MKK Unnes.

Checkley, D. 2010. High School Students' Perceptions of Physics, Faculty of Education. Lethbridge, Canada

Djamarah, 2011, Guru dan Anak Didik Dalam Interaksi Edukatif, Jakarta: Rineka Cipta.

Elwan, A.A,. Serage, M., \& Alwan, A. 2013. The Institutional Factors Affecting The Achievement in Physics in Tripoli. Libya. VFAST Transactions on Research in Education,1(2), 1-18.

Hamalik, O. 2006. Proses Belajar Mengajar. Bandung: Bumi Aksara.

Marantika, I. 2007. Pengaruh Keaktifan Organisasi Ekstrakurikuler dan Motivasi Belajar Terhadap Prestasi Belajar Mahasiswa. Skripsi. Malang: Fakultas Ekonomi Universitas Negeri Malang.

Rusilowati, Ani. 2006. Profil Kesulitan Belajar IPA Pokok Bahasan Kelistrikan Siswa SMA di Kota Semarang. Jurnal Pendidikan IPA Indonesia. 4 (2), 100-106.

Sugiyono. 2010. Metode Penelitian Pendidikan Pendekatan Kuantitatif, Kualitatif dan R\&D (Edisi Kelima). Bandung: Alfabeta.

Suyanto. 2007. Pengaruh Strategi Pembelajaran Dan Bakat Terhadap Hasil Belajar Pemahaman Konsep Teknik Otomotif Di SMKN 1 Trenggalek. Jurnal Pendidikan Profesional, 5(1).

Ukoh, E.E. 2012. Effect of Interactive Invention Instructional Strategy on NCE Pre-Service Teacher's Achievement in Physics and: Acquisition of Science Process Skills. Journal of Innovative Research in Management and Humanities, 3(1): 122- 131.

Ornek, F., Robinson, W., \& Hugan, M. 2008. What Makes Physics Difficult?.International Journal of Environmental \& Science Education, 3 (1): 30-34.

Wahyudi. 2006. Pelaksanaan Remedial Bagi Anak Berkesulitan Belajar Membaca Permulaan Kelas II SD . Jurnal Guru volume 03 no.1 hal 81 : Dinas Pendidikan Kota Padang Panjang. 